DOI 10.18551/rjoas.2019-04.15

\title{
INPUT-OUTPUT ANALYSIS FOR AGRICULTURAL SECTOR IN THE ECONOMY STRUCTURE OF ACEH PROVINCE, INDONESIA
}

\author{
Sari Cut Rozana*, Student \\ Magister Program of Agribusiness, Syiah Kuala University, Indonesia \\ Zakiah, Nugroho Agus \\ Department of Agribusiness, Syiah Kuala University, Indonesia \\ *E-mail: cutrozanasari@gmail.com
}

\begin{abstract}
Agriculture is one of the most dominant sectors in Indonesian people's income because the majority of Indonesia's population works as farmers. An economy is said to experience growth if the economy level achieved is now higher than achieved in the previous year. The greater growth in each sector means the contribution to economic development in the country or region is getting higher, so that the level of welfare will be better. High construction growth illustrates that to support every economic activity sector is needed. The purpose of this study is to analyze the role of the agricultural sector in the Aceh Province economy structure. This study used Input-Output Tables of 1998, 2006 and 2012. The results of the study shown that the agricultural sector has an important role in the Aceh Province Economy Structure, as evidenced by the increase in output throughout the year. Besides producing high output, the agricultural sector was the largest sector in creating added value.
\end{abstract}

\section{KEY WORDS}

Agricultural sector, input-output analysis, output structure, value added structure.

Agriculture is one of the most dominant sectors in Indonesian people's income because the majority of Indonesia's population works as farmers. But agricultural productivity is still far from expectations. One of the factors causing lack of agricultural productivity is human resources are still low in processing agricultural land and results. The majority of farmers in Indonesia still use manual systems in processing agricultural land.

An economy is said to experience growth if the economy level achieved is now higher than achieved in the previous year. The greater the growth in each sector means the contribution to economic development in the country or region is getting higher, so that the level of welfare will be better.

Regional development planning that has been carried out so far, is still partial and has not been able to detect how the influence of investment in a sector on the economic structure of a region. This failure causes in the implementation of planning, for that we need an analysis model that can integrate development planning of a region.

Planning Economic growth is the goal of development, where both have a related relationship. Post-2004 tsunami had an influence on the development of the economic sector, especially the agricultural sector, which is one of the important sectors in economic development in Aceh Province. In 2005 the agricultural sector had a negative growth rate. The development of the growth rate in each sector has a relationship with other sectors. After the tsunami, many agricultural lands in Aceh Province were built for housing, hotels, restaurants and buildings for trade so that the sector had a positive growth rate.

In order to develop an area, with the aim of improving the community welfare, the regions will develop economic sectors in accordance with their superiority. The economic sector is said to have advantages because the sector is capable of producing high output and added value. In addition to producing output and added value, the leading sector also produces exports are able to provide foreign exchange for regional development (Suharto, 2002). 


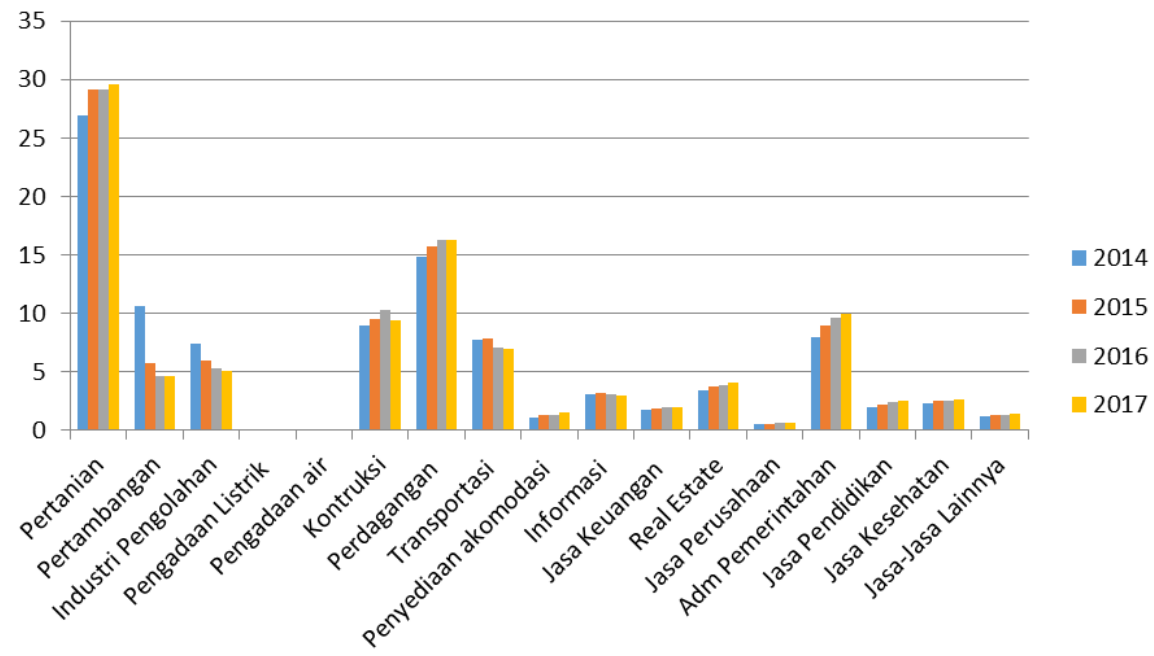

Figure 1 - Percentage Distribution of PDRB by Business Field (Percent) in Aceh Province, 2014-2017 (Source: Aceh Province Central Statistics Agency 2018)

The biggest contribution to economic development in Aceh, given by the agricultural sector is 26.93 percent even though the growth rate of this sector in 2017 is smaller at 5.21 percent compared to the growth rate of the construction sector, which is 12.96 percent. High construction growth illustrates that to support every economic activity sector is needed. The purpose of this study is to analyze the role of the agricultural sector in the Aceh Province economy sector.

\section{METHODS OF RESEARCH}

The study took place in the Aceh Province which is located at the tip of Sumatra Island. Aceh Province had diverse potential characteristics. Aceh Province is located at 01058'37.2 '06 $04^{\prime} 33.6$,6 North Latitude and 94 57 '57.6 - - $98^{\circ} 17^{\prime}$ '13.2' East Longitude, with an average height of $125 \mathrm{~m}$ above sea level.

This study used the Input-Output Tables of 1998, 2006 and 2012. The Input-Output tables used to evaluate development outcomes through economic analysis used for planning materials. The object of this research was the agricultural sector. Based on the background, objectives and formulation of the problem, the scope of this research was analyze the role of the agricultural sector

This study used the Input-Output Tables of 1998, 2006 and 2012. Where 1998 consisted of 30 sectors, 2006 consisted of 55 sectors and in 2012 consisted of 66 sectors. Then by used leontife inverse matrix all sectors each year, namely 1998, 2006 and 2012 to 13 sectors, used the $13 \times 13$ matrix sector as found in the BPS Input-Output Table. This category included all economic / business activities, which include the agricultural sector.

Output was the production value of goods and services produced by economic sectors. Where total output was equal to total input (Daryanto and Yundy, 2010b). If the input used equal to one, the output produced also equal to one. The equation can be written as follows:

$$
\mathrm{i}=1 \mathrm{n}=\mathrm{Z} \mathrm{X}_{\mathrm{i}}={ }_{\mathrm{j}}=1 \mathrm{n} \mathrm{X}_{\mathrm{j}}
$$

Where: $X_{i}=$ Total output of economic sector (i); $X_{i}=$ Total input of economic sector (j).

If the total input of sector $i$ is equal to one, the amount of output produced by sector ${ }_{i}$ is equal to the number of inputs used by sector ${ }_{j}$. If the total input sector $>1$ then the amount of output produced by sector ${ }_{j}$ is also greater, and conversely if the total input of sector ${ }_{i}<1$, the output produced by sector $\mathrm{j}$ will also be smaller.

Added value was the remuneration created for production factors that play a role in the production process. Where the service covers the components, namely wages, salary, 
business surplus, depreciation, and indirect taxes (Saragih, 2003). The equation can be written as follows:

$$
V_{j}={ }_{j}=1 n V_{i j}
$$

Where: $V_{j}=$ Primary input from other economic sectors $(j) ; V_{i j}=$ The amount of output sector (i) used as input by sector $\left({ }_{j}\right)$.

If $V_{j}$ is equal to one then the structure of ${ }_{j}$ value added sector is equal to the average value added structure of sector ${ }_{i}$, if $V_{j}>1$ then the value added structure of sector ${ }_{j}$ is greater than the average ${ }_{i}$, and if $V_{j}<1$ then sector value added structure ${ }_{j}$ lower than ${ }_{i}$.

\section{RESULTS AND DISCUSSION}

The results of the first objective analysis aims to looked at the role of the agricultural sector in the Aceh Province economy structure, can also be seen through an analysis of the InputOutput Table. The Aceh Province Input-Output Tables of 1998, 2006 and 2012 consists to 13 sectors. The output defination in this study was the entire production value of goods and services produced by economic sectors in Aceh. The analysis of the output structure was intended to gave an overview of which sectors were able to contribute high to the formation of the overall output.

The total output produced by economic sectors in Aceh from 1998, 2006 to 2012 continues to experience significant increases. In 1998 the total output was recorded at Rp. 34,265,931 million, and experienced an increase in 2006 which reached Rp. 123,779,495 million or about three times that of 1998 . Total output also increased by 32 percent, reached Rp. 163,767,771 million in 2012 can be seen in figure 1 below.

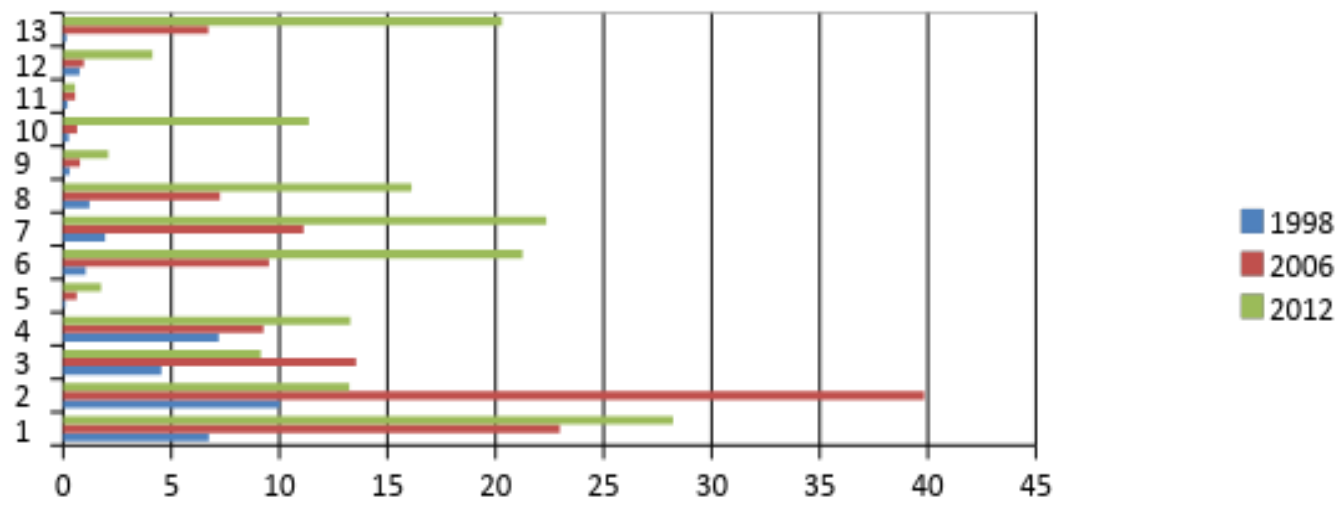

Figure 2 - Largest Sectors According to Aceh Province Output Rating in 1998, 2006 and 2012 (Source: Table IO results of Aceh Province 1998, 2006, 2012; processed)

If seen from the number of outputs produced by sector, it can be seen that there are four sectors which are the most dominant sectors from 1998 to 2012. These sectors were (1) agriculture, (2) mining and quarrying sector, (3) industrial sector agricultural processing and (6) construction sector. When viewed from the amount of output produced, the sector was the leading sector that needs attention from the government in order to develop the regional economy.

If viewed from the amount of outputs produced by sector, it can be seen that these four largest sectors according to output ratings as presented in Table 1. The agricultural sector was an sector that has increased output from 1998, 2006 to 2012. In 1998 the agricultural sector could create output Rp. 6,739,731 million or 13.67 percent and in 2006 the agricultural sector experienced an increase in the production of Rp. 22,975,262 million or 18.56 percent of all output then in 2012 the agricultural sector accelerated in the creation of output, which amounted to Rp. 28,214,418 million or 20.16 percent of the total output produced in 2012 . 
Table 1 - The Four Largest Sectors According to Output Ranks for Aceh Province Year 1998, 2006 and 2012 in Million

\begin{tabular}{|c|c|c|c|c|c|c|c|}
\hline \multirow{2}{*}{ code } & \multirow{2}{*}{ Sector } & \multicolumn{2}{|l|}{1998} & \multicolumn{2}{|l|}{2006} & \multicolumn{2}{|l|}{2012} \\
\hline & & Output & $\%$ & Output & $\%$ & Output & $\%$ \\
\hline 1 & agriculture (agriculture, forestry, and fisheries) & $6,739,731$ & 13.67 & $22,975,262$ & 18.56 & $28,214,418$ & 20.16 \\
\hline 2 & mining and quarrying sector & $10,022,708$ & 33.84 & $39,833,044$ & 32.18 & $13,237,157$ & 6.87 \\
\hline 3 & industrial sector agricultural processing & $4,359,255$ & 17.08 & $13,548,238$ & 10.95 & $9,138,802$ & 1.21 \\
\hline 6 & Construction & $1,040,474$ & 7.79 & $9,645,406$ & 7.69 & $21,250,239$ & 12.82 \\
\hline \multicolumn{2}{|c|}{ The amount of output ratings (1-4) } & $22,162,168$ & 72 & $86,001,950$ & 69.38 & $71,840,616$ & 41.06 \\
\hline \multicolumn{2}{|c|}{ Other Sector } & $12,103,763$ & 28 & $37,777,545$ & 31 & $91,927,155$ & 59 \\
\hline \multicolumn{2}{|c|}{ Total } & $34,265,931$ & 100 & $123,779,495$ & 100 & $163,767,771$ & 100 \\
\hline
\end{tabular}

Source: IO Table Results of updating Aceh Province in 1998, 2006 and 2012 (processed).

The amount of added value in each sector was determined by the amount of output (the amount of production value) produced and the amount of costs incurred in the production process (Hotman, 2006). Therefore, a sector has a large output value does not necessarily have a large added value. It was because, in added value, also calculated the amount of production costs incurred by a sector in carrying out activities.

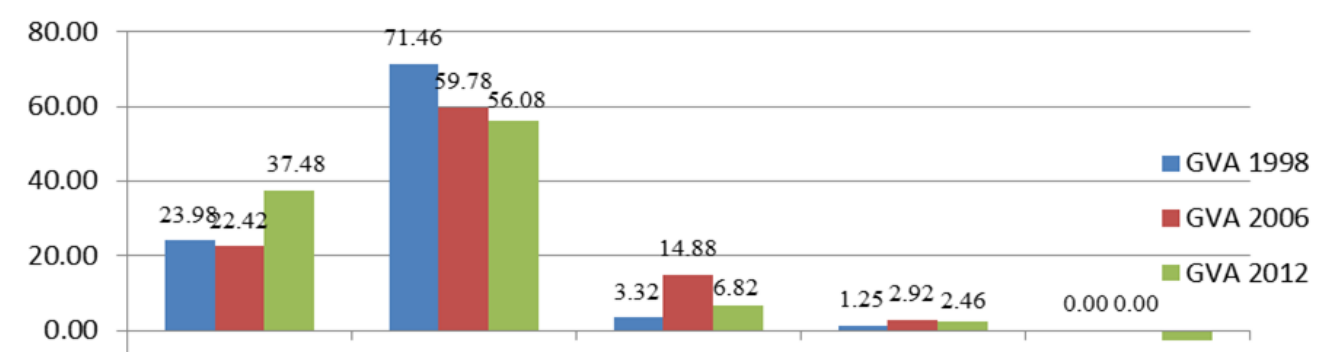

Figure 3 - Composition of Gross Added Value according to the Components of Aceh Province in 1998,2006 and 2012 (Source: Table IO results of Aceh Province 1998, 2006, 2012; processed)

In the figure above the amount of gross added value according to the components in Aceh Province. The gross value added component consists of wages and salaries, business surplus, depreciation, indirect taxes and subsidies. In Figure 2 for 2012 it was known that the gross value added component in Aceh was allocated to wages and salaries of 37.48 percent. Furthermore, it was allocated a business surplus of 56.08 percent, allocated for depreciation of 6.82 percent, and 2.46 percent allocated for indirect taxes.

Table 2 - The Four Largest Sectors by Ranking the Gross Value Added of Aceh Province in 1998, 2006 and 2012 in Million

\begin{tabular}{|c|c|c|c|c|c|c|c|}
\hline \multirow{2}{*}{ code } & \multirow{2}{*}{ Sector } & \multicolumn{2}{|l|}{1998} & \multicolumn{2}{|l|}{2006} & \multicolumn{2}{|l|}{2012} \\
\hline & & Output & $\%$ & Output & $\%$ & Output & $\%$ \\
\hline 1 & agriculture (agriculture, forestry, and fisheries) & $5,740,563$ & 22.40 & $14,837,253$ & 21.70 & $21,406,402$ & 19.75 \\
\hline 2 & mining and quarrying & $9,767,586$ & 38.12 & $25,289,392$ & 36.99 & $11,378,390$ & 10.50 \\
\hline 3 & $\begin{array}{l}\text { Wholesale and retail trade, repair and } \\
\text { maintenance of cars and motorbikes }\end{array}$ & $1,053,370$ & 4.11 & $7,739,085$ & 11.32 & $16,296,334$ & 15.04 \\
\hline 6 & other services & 119,817 & 0.46 & 353,1304 & 5.16 & $14,604,643$ & 13.47 \\
\hline \multicolumn{2}{|c|}{ The amount of output ratings (1-4) } & $16,681,336$ & 65.09 & $51,397,034$ & 75.17 & $63,685,769$ & 58.76 \\
\hline \multicolumn{2}{|c|}{ Other Sector } & $8,939,253$ & 34.91 & $16,959,572$ & 24.83 & $44,659,113$ & 41.24 \\
\hline \multicolumn{2}{|c|}{ Total } & $25,620,589$ & 100 & $68,356,606$ & 100 & $108,344,882$ & 100 \\
\hline
\end{tabular}

Source: IO Table Results of updating Aceh Province in 1998, 2006 and 2012 (processed).

The results of the analysis in Table 2 shown that agriculture was the largest sector in creating value added. Besides being large in the creation of output this sector was also capable of producing relatively large added value, aims in 1998 the agricultural sector was able to create added value of $\mathrm{Rp}$. 5,740,563 million then the agricultural sector experienced an increase in 2006 which was Rp. 14,837,253 million and in 2012 the agricultural sector continued to experience an increase of Rp. 21,406,402 million. The Agriculture Sector was able to produce relatively large added value because in addition to meeting domestic needs, 
this sector is also able to export most of its output. Then the mining and quarrying sectors, the wholesale and retail trade, repair and maintenance of cars and motorbikes, and other services sectors respectively.

\section{CONCLUSION} as follows:

Based on the results of research and discussion have been done it can be concluded

1. The agricultural sector has an important role in the structure of the economy in Aceh Province. The agricultural sector experienced an increase in output in 1998, 2006 and 2012 in the input output table, in 1998 the agricultural sector produced an output of Rp. 6,739,731 million increased in 2006 amounting to Rp. 22,975,262 million in 2012 the agricultural sector produced an output of Rp. 28,214,418 million;

2. Increased output throughout the year can be interpreted that the agricultural sector has an important role in the structure of the economy in Aceh Province. In addition to producing high output, the agricultural sector also has relatively large added value to the economy in Aceh Province.

\section{REFERENCES}

1. Badan Pusat Statistik. 1998. Tabel Input-Output Provinsi Aceh Tahun 1998. Badan Pusat Statistik, Banda Aceh.

2. 2006. Tabel Input Output Provinsi Aceh Tahun 2006. Badan Pusat Statistik, Banda Aceh. 2012. Analisis Perekonomian Provinsi Aceh Model Tabel Input Output. Badan Pusat Statistik, Banda Aceh.

3. 2017a. Keadaan Geografis Wilayah Provinsi Aceh. Badan Pusat Statistik, Banda Aceh.

4. Daryanto, A. and Y. Hafizrianda. 2010a. Analisis Input-Output \& Social Accounting Matrix Untuk Pembangunan Ekonomi Daerah. Penerbit IPB Press, Bogor.

5. Elviana. 2012. Analisis Keterkaitan Antar Sektor Ekonomi di Provinsi Aceh: Pendekatan Input Output. Tesis Sekolah Pasca Sarjana Institut Pertanian Bogor, Bogor.

6. Saragih, W.S. 2003. Peranan Sektor Pertanian dalam Pembangunan Ekonomi Di Provinsi Sumut (Pendekatan Input-Output). Tesis Magister Sains. Sekolah Pascasarjana Institut Pertanian Bogor, Bogor.

7. Suharto. 2002. Disparitas and Pola Spesialisasi Tenaga Kerja Industri Regional and Prospek Pelaksanaan Otonomi. Jurnal Ekonomi Pembangunan, 7(1): 33-44.

8. Wang lu. \& T. Rencheng. 2007. Input-Output Analysis for Multi-location Supply Chain Management Control: A Theoretic Model. http://www.google.co.id [12 Agustus 2011]. 